\title{
Has God Indeed Said? Skeptical Theism and Scriptural Hermeneutics ${ }^{1}$
}

\author{
Michelle Panchuk \\ Murray State University
}

\begin{abstract}
: this paper demonstrates that the skeptical theist's response to the problem of evil deprives the analytic theologian of theoretical resources necessary to avoid accepting as veridical merely apparent divine commands that endorse cruelty. In particular, I argue that the same skeptical considerations that lead analytic theologians to endorse skeptical theism also lead to what I call "divine command skepticism"an inability to make certain kinds of judgements about what a good God would or would not command. The danger of divine command skepticism is not that it generates new reasons to think that God has commanded horrors, but, rather, that it undercuts the defeaters we might otherwise have for thinking that God has commanded those horrors. It does so both by rendering illicit certain theological and hermeneutical methodologies employed within liberatory frameworks (i.e., various kinds of liberation theologies) and by depriving the theologian of some of the more "traditional" mechanisms for resolving such apparent conflicts.
\end{abstract}

Now the serpent was more cunning than any beast of the field which the Lord God had made. And he said to the woman, "Has God indeed said, 'You shall not eat of every tree of the garden'?" Genesis 3:1, NKJV²

As the story goes, the first human sin grows out of a seed of doubt about the nature and intent of God's command. First the serpent encourages Eve to doubt the content

\footnotetext{
${ }^{1}$ I thank the attendees at the 2018 Theistic Ethics Workshop and a session at the 2019 Central Regional Conference of the Society of Christian Philosophy for helpful comments on this paper. A special thanks to Michael Rea for invaluable comments on an earlier draft, to three anonymous reviewers, and the editorial team at the Journal of Analytic Philosophy.

${ }^{2}$ All Biblical citations are from the New King James Version, unless otherwise specified.
}

Journal of Analytic Theology, Vol. 9, Summer 2021

10.12978/jat.2021-9.120804150010

(C) 2021 Michelle Panchuk • (C) 2021 Journal of Analytic Theology 
of the command, and then it moves on to challenge the command's goodness: "for God knows that in the day you eat of it your eyes will be opened, and you will be like God, knowing good and evil" (Genesis 3:5). The serpent's not-so-subtle inference is that a God who had their best interests at heart would not forbid such valuable knowledge. As the author of the epistle to Timothy later interprets the text, Eve is genuinely deceived, either about what is good for her or about God's loving care for her (1 Timothy $2: 14)$. She sins, and invites her husband to sin with her, because she draws improper conclusions about what a loving God would command or had commanded. As the story goes, the first humans are exiled from paradise, condemned to toil and suffer in the production of food and in reproduction. One apparent moral of the story is: doubting divine commands leads to disobedience, and disobedience leads to suffering.

Yet, some of the greatest atrocities in history have been enabled by the failure of otherwise reasonable and decent people to question whether God really has, or could, command the horrors they enacted in the divine name. Certainly some participants in the Crusades, in the Inquisition, in acts of religious terrorism, and in religiously-motivated child abuse, have simply co-opted religion as the handiest club with which to bludgeon their neighbor. ${ }^{3}$ But not all. Some participants in such horrors appear to have genuinely believed themselves to be fulfilling the will of God. Nothing is more terrifying than a true believer. The true believer cannot be bought, is not easily discouraged, not likely persuaded. In the words of C. S. Lewis, "those who torment us for our own good will torment us without end for they do so with the approval of their own conscience" (Lewis, 292). ${ }^{4}$

This puts religious believers, finite and fallible as we are, in a potentially difficult spot. To unquestioningly follow merely ostensible divine commands can, under certain conditions, make us into instruments of unspeakable cruelty. To refuse the goodness of genuine commands of a loving and all-wise God is to separate oneself from the good. This paper makes no attempt to provide guidance in the face of such high stakes. I leave that to other theologians and biblical scholars. Rather, I seek to demonstrate that one approach to the problem of evil deprives the analytic theologian of the theoretical resources necessary to avoid the first horn of this dilemma. In particular, I argue that the same skeptical considerations that lead analytic theologians to endorse skeptical theism also lead to what I call "divine command skepticism" - an inability to make certain kinds of judgements about what a good God would or would not command. The danger of divine command skepticism is not that it generates new reasons to think that God has commanded horrors, but, rather, that it undercuts the considerations that might otherwise defeat the reasons that many believers already take themselves to have for believing that God has issued apparently grotesque commands. It does so both by rendering illicit certain theological and hermeneutical methodologies employed within liberatory frameworks (i.e., various kinds of liberation theologies) and by depriving the theologian of some of the more "traditional" mechanisms for resolving such apparent conflicts. To put it more concretely, there are quite a number of places in the Christian Scriptures where it appears

${ }^{3}$ A metaphor Marylin McCord Adams sometimes used.

${ }_{4}^{4}$ This seems true quite apart from whether Lewis's argument for retributive punishment is a good one. 
that God has commanded or endorsed horrors-the Canaanite genocide, slavery, requiring a woman to marry her rapist, stoning rebellious children, just to name a few examples. Many Christians want to deny that God endorses or has ever endorsed such things, but the hermeneutical mechanisms many Christians employ-those that appeal implicitly or explicitly to the moral badness of the putative command-to arrive at this conclusion are rendered illegitimate by Divine Command Skepticism.

\section{The Skepticism of Skeptical Theism}

Religious people of all stripes must grapple with the ubiquity of suffering in our world. Indeed, confrontation with the reality of suffering is what inspires the Buddha to pursue enlightenment and eventually to embrace the middle way, avoiding desire and attachment in order to find release from suffering. Within Buddhism and several other religions originating on the Indian subcontinent, various kinds of suffering, small and great, are the result of karma-the consequences of the individual's actions in this life or a previous one. For traditional monotheists (henceforth, simply "theists") though, the existence of apparently gratuitous suffering is not exclusively a reality that the religion aims to ameliorate, but a problem that apparently undermines the consistency of the theist's religious beliefs. If an omniscient, omnipotent, omnibenevolent God exists, it seems as though there should be no gratuitous suffering in the universe. Here I use "gratuitous" to describe suffering that does not serve any greater good or higher purpose. Whether there is actually any such suffering is a matter of significant debate. However, it certainly appears to many of us, at least on the face of it, that there is a great deal of gratuitous suffering, whether or not there actually is. The Rwandan genocide, the holocaust, the holodomor (the man-made famine/genocide in Ukraine in the early 1930s), chattel slavery, the Trail of Tears, the apparent ubiquity of sexual abuse within religious communities (Katzenstein and Fontes 2017; Zalcberg 2017; Grand Jury 2018; Downen et. al. 2019), and the havoc that it can wreak on one's spirituality (Tobin 2016; 2019; Panchuk 2018; 2020) all seem like prime examples. Not only do many of these examples involve evils committed with religious appeals to divine revelation as their justification, they also fall under what Marilyn McCord Adams calls horrendous suffering. Horrendous evils are unique not only in their apparent gratuitousness, but also in the degree to which they destroy the possibility of positive meaning in the sufferer's life. Adams defines horrendous sufferings as, "evils, the participation in which (that is, the doing or suffering of which), constitutes prima facie reason to doubt whether the participant's life could (given their inclusion in it) be a great good to [them] on the whole" (Adams 1999, 26). One thinks of the holocaust victim who survives a proverbial hell on earth only to be claimed by suicide because they cannot make any positive meaning out of a life that contains such degradation (Brison 2002, 65), Ivan's child living in the wake of her unanswered cry to "dear, kind God" (Dostoyevksy 1937, 251), or the religious trauma survivor who cannot seem to maintain any positively-meaningful relationship with God in the wake of religious traumatization (Panchuk 2018; Rea 2019, 137-179). Jean Améry even goes so far as to claim that "whoever is tortured, stays tortured" (Améry 1995, 131, 
ctd. in Brison 2002, 65). For some people, there appears to be no positive meaningmaking in the wake of some kinds of suffering. ${ }^{5}$ This is perhaps most arresting when, as is our current concern, an ostensible attempt to follow divine commands is what destroys that possibility.

Skeptical Theism is a family of views held in response to the problem posed to theists by apparently gratuitous suffering. Quite a number of different versions and formulations of skeptical theism are now on offer, but what they all have in common is the argument that even if an omniscient, omnipotent, omnibenevolent God has morally justifying reasons for allowing horrific suffering, finite and epistemically limited beings like us shouldn't expect to have epistemic access to those reasons. When presented with an atheistic argument such as the following, the skeptical theist will challenge the inference from (A1) to (A2):

(A1): There are some evils that are such that humans can't think of any Godjustifying reason for permitting them.

(A2) So probably there aren't any God-justifying reasons for permitting those evils.

(A3) If God existed, [God] wouldn't permit these evils if there were no Godjustifying reason for permitting them.

(A4) Therefore, probably God does not exist. (Bergmann 2011, 374)

Humans, the skeptical theist will say, just are not in a position to infer from their inability to see, or even imagine, a reason that would justify God in allowing some bit of suffering, that there is no such reason. Michael Bergmann suggests that skeptical theism is committed to the following skeptical theses:

(SC1) We have no good reason for thinking that the possible goods we know of are representative of the possible goods there are.

(SC2) We have no good reason for thinking that the possible evils we know of are representative of the possible evils there are.

(SC3) We have no good reason for thinking that the entailment relations we know of between possible goods and the permission of possible evils are representative of the entailment relations there are between possible goods and the permission of possible evils.

\footnotetext{
${ }^{5}$ It is important to note that the experience of a particular kind of suffering and of its aftermath in their life differs widely across persons. Some survivors of severe child-abuse are unable to "recover" enough to live outside of an institutional context, while others go on to write books about finding hope in the wake of suffering. Many survivors of the holocaust did in fact commit suicide; but others, like Viktor Frankel, went on to write books about inviolability of the possibility of meaning making in the wake of Auschwitz (1959). This may just point to the fact that whether or not a particular instance of suffering is "horrendous" is not always a function of the externally observable features of the suffering. It is likely a complex function of those features, the individual sufferer's biology, previous life experiences, features of their community before and after the suffering, availability of resources after the fact, etc. My point is not that everyone who experiences a particular kind of suffering is deprived of the ability to make meaning, but that some appear to be, and for reasons that do not seem reducible to their personal choices.
} 
(SC4) We have no good reason for thinking that the total moral value or disvalue we perceive in certain complex states of affairs accurately reflects the total moral value or disvalue they really have. (2011, 379-382; 379)

If these accurately characterize the limits of human knowledge and the sort of epistemic humility that we should have with respect to the realm of value and to God (if the God of classical theism exists), then, says the skeptical theist, we cannot make the atheistic inference presented above. Michael Rea characterizes the central thesis of skeptical theism as the claim that:

(ST) No human being is justified (or warranted, or reasonable) in thinking the following about any evil $e$ that has ever occurred: there is (or is probably) no reason that could justify God in permitting e. (Rea 2013, 483)

A common critique of skeptical theism attempts to demonstrate that while (ST) may seem initially plausible, accepting it would commit us to more general and unwelcome forms of moral skepticism (Sehon 2010; Bergmann 2011,386ff; Rea 2013; Maitzen 2013; 2014; Rutledge 2017). Of particular interest in the current context is an exchange between Stephen Maitzen and Michael Rea about one kind of moral skepticism. Maitzen argues that skeptical theism undermines the religious believer's ability to recognize, prioritize, and obey divine commands, because the finite human just cannot know what reasons a being like God might have to command various things. Rea responds by noting that within theistic traditions there are rich and nuanced theological frameworks for identifying, interpreting, and applying divine revelation. Most theists don't identify a particular text as religious scripture or human imperatives as revelations of divine commands just by reflecting on what kinds of things God might have reason to say or to command, but based on carefully developed criteria. Within Christianity, we have various theological traditions of scriptural interpretations and methodologies. Devout Christians read the Bible prayerfully, asking for the assistance of the Holy Spirit and in conversation with Christians past and present. Judaism has the Talmud, Midrash, and a wealth of traditional rabbinic Biblical interpretation. In Islam there is even a tradition of interpreting some putative revelations as inspired by Satan. According to the tradition, after the Prophet Muhammad's audience understood him to have endorsed their idols, the Angel Gabriel revealed to him that what he mistakenly took to be divinely inspired was actually inspired by Satan (Ahmed 1998; Moosa 2008; Mizrahi forthcoming). Moti Mizrahi argues that this raises a skeptical worry that other passages of the Qu'ran might also be "satanic verses" (forthcoming), a worry that Muslim theologians could address from within the robust tradition of the Hadith and Qu'ranic interpretation. Rea claims that Maitzen offers no reasons to think that these Christian methods are flawed, and, though Rea focuses on Christianity, the same could be said of the other traditions described (Rea 2013, 498).

In the current paper I do not wish to render judgement on the outcome of this debate between Rea and Maitzen. Instead, I argue that insofar as traditions of scriptural hermeneutics rely on assumptions about the moral reasons a being like God (or 
Allah) might have, it is precisely these sorts of interpretive moves that the skepticism of skeptical theism ultimately renders illegitimate. In the next section, I demonstrate that if our epistemic limits give us good reason to accept (ST), then they also count in favor of what I will call Divine Command Skepticism (DCS). If the skeptical theist must accept DCS then we do have a reason to think that there is an inconsistency between at least some common hermeneutical practices and skeptical theism.

\section{Divine Command Skepticism}

If proper epistemic humility motivates the skeptical theist to accept SC1-SC4, it should also motivate the skeptical theist to accept the following:

$\left(\mathrm{SC}^{*}\right)$ We have no good reason for thinking that the total moral value or disvalue we perceive in certain complex states of affairs-including obedience to certain ostensible divine commands-accurately reflects the total moral value or disvalue they really have.

(SC5) We have no good reason for thinking that the entailment relations we know of between possible goods and possible evils and obedience to certain ostensible divine commands are representative of the entailment relations there are between possible goods and possible evils and obedience to certain ostensible divine commands.

(DCS) No human being is justified (or warranted, or reasonable) in thinking the following about any ostensible divine command $c$ or endorsement $e$ that is (i) logically consistent and (ii) does not require the performance of an action that is an absolute moral wrong: there is (or is probably) no reason that could justify God in issuing command c or endorsement $e^{6}$

The final principle (DCS) characterizes what I have been calling Divine Command Skepticism-the principle that we should be skeptical of our ability to evaluate whether there are God-justifying reasons for issuing any particular divine command. Let's consider these theses in turn. First, (SC4*) is just a specific instance of the more general thesis (SC4), so if one accepts the later, they should also accept the former. Second, (SC5) is a close cousin to (SC3). If our epistemic limitations should lead us to be skeptical about our knowledge of the entailment relations that hold between possible goods and permissions of possible evils, then we should also be skeptical about our knowledge of the entailment relations that hold between possible goods and possible evils and obedience to certain ostensible divine commands. If I don't have reason

${ }^{6}$ The phenomenal conservative might point out that SC1-SC5 leave open that one can be justified in believing that God could not have a morally sufficient reason for commanding $c$, just if it seems to her that God lacks a sufficient reason and she has no defeater for her belief. If phenomenal conservatism is correct, then this is also a more general weakness that ST suffers from. That is, an atheist could know non-inferentially that there is no God-justifying reason for allowing some evil. Since my goal is to suggest that someone who accepts ST should also accept DCS, I will not address this sort of worry here. (See Tucker 2014). I thank Chris Tucker for a helpful conversation on this topic. 
to think I know all the possible evils and possible goods there are, I probably don't have reason to think I know all the goods that might be achieved and evils that might be avoided by complying with any particular divine command, despite how things might appear to me. Skeptical theists often use examples such as the following to prime for their skeptical intuitions. As a toddler, my daughter didn't know of the possible evils of various childhood illnesses. She also wasn't in a position to know about the entailment relations that held between my permission of her suffering the pain of an injection of a vaccine and the prevention of those evils. But, so the argument would go, that very same ignorance explains why she wasn't in position to know the entailment relations that held between my telling the doctor to give her the injection and my instructing her to try to be still. If she is justified in trying to obey me and allowing the doctor to give her the injection, despite appearances that getting a shot is quite bad, so also should humans obey God even when it seems to us that obeying God would be quite bad. So, if our epistemic humility requires (SC3) it should also lead us to accept (SC5).

Finally, if one is inclined to accept that (SC1)-(SC4) are good reasons to think that (ST) is true, then I argue that one should also accept that they, together with (SC4*) and (SC5), provide equally good reasons for thinking that we are not in a good position to assess what kinds of reasons God might have for issuing divine commands that, on their face, seem morally dubious. But as we should expect, given the nature of our skeptical theses, this only applies to those ostensible divine commands that we lack reasons to reject apart from our judgements about what reasons God might have (or lack). One might think that God could not command a contradiction-something of the form $\mathrm{C}(\phi$ and $\sim \phi)$ - because a perfectly rational being could not will or desire a contradiction. ${ }^{7}$ Further, the theist who thinks that some action types are absolutely morally wrong, regardless of the goods they produce or the evils they avert, will have grounds, apart from their knowledge of the realm of value, to reject as veridical a divine command that includes the performance of such actions. A theist who is an absolutist about lying-one who thinks that lying is always wrong regardless of the intentions of the speakers, the goods that might be achieved, and evils that might be averted by lying - would have reasons not undermined by the kind of epistemic humility characterized by our skeptical theses to reject the divine command to lie as veridical (e.g., Tollefsen 2016). An absolute pacifist theist who thinks that all killing is always morally wrong will have reasons not undermined by (DCS) to reject ostensible divine commands that involve killing another person (Hereth 2017). ${ }^{8}$ What the skeptical theist is not in a position to do is reason from their inability to see or imagine any

\footnotetext{
${ }^{7}$ I thank Michael Rea for helpful comments on this point.

${ }^{8}$ This qualification will not help in a number of cases because whether the action would fall under the action type that is absolutely forbidden is often precisely what is in question. An anonymous referee suggested that the skeptical theist could easily respond to the example offered below by claiming that child abuse is an absolute moral wrong. The problem is that whether a particular act of ostensible harm to a child counts as abuse often depends on effects of that action, as the vaccination case shows. Furthermore, whether someone with the kind of epistemic humility characterized by (ST1)-(ST5) would be willing to rely on their moral commitments over and above whatever reasons
} 
morally sufficient reason for God to command $c$ to the conclusion that God could not have such a reason.

Perhaps this is too hasty though. On the face of it, there is an incongruity between (ST) and (DCS). (ST) only claims that our knowledge of the realm of value isn't expansive enough to warrant the judgement that God lacks reason for permitting evil. But some philosophers think that there is an important moral difference between merely permitting evils and actively causing them (Bennett 1967; Quinn 1989; Rachels 2001). If one is inclined to embrace the doing vs. allowing distinction in the case of God, ${ }^{9}$ then one might also see an important moral difference between permitting evils and actively commanding or endorsing them. If this view is correct, then (DCS) is a stronger moral claim than (ST). I will assume for the sake of argument that this is correct, and that one could theoretically be unjustified in concluding that God lacks a justifying reason for allowing some evil $e$, but simultaneously be justified in drawing the conclusion that God lacks a morally sufficient reason for commanding or endorsing $e$. This, however, is insufficient for the skeptical theist to avoid the force of my concern. If the skeptical theist accepts (SC1)-(SC4) or something like those, I have already argued that they should also accept (SC4*) and (SC5). Whether or not issuing a command is morally permissible often depends in part on the goods that obeying it would bring about or the evils it would avert, just as whether or not standing by and merely allowing an evil to occur rather than intervening depends, in part, on what goods may be achieved or evils averted by doing so. The person who thinks that God's permission of a certain evils prevents some unknown worse evil or achieves some good that appears to us to be logically unrelated to it, should also acknowledge that God's commanding or endorsing certain actions could (unbeknownst to us) prevent some other worse evil or achieve some good that appears to us to be logical unrelated to it. It would be surprising for a skeptical theist to believe that we are not in a position to know that there aren't any God-justifying reasons for allowing some evil $e$, but for that same skeptical theist to believe that we are in a good position to know that there aren't any God-justifying reasons for commanding $e^{*}$ (except in those cases that are ruled out by (DCS), discussed above).

In this section I have argued that the considerations that motivate skeptical theism also count in favor of (DCS) or some relevantly similar principle. In the next section I turn to the problematic implications of accepting (DCS).

\section{The Skepticism of Divine Command Skepticism}

The problems raised by (DCS) are substantially narrower than the more familiar worries about global moral skepticism or even Maitzen's skepticism about divine commands. God has whatever moral reasons God has, and neither (DCS) nor (ST) generate any new reasons for God. Nor does (DCS) generate any new reasons for us to believe that God has morally sufficient reasons to command or endorse things that we

they might have for thinking the command is veridical is another question beyond the scope of this paper. It is presumably cases like this that Rea's comments are intended to address (Rea 2013, 498).

${ }^{9}$ For an argument that this distinction breaks down in the case of God, see Lim (2017). 
previously had no reason to think that God commanded or endorsed. Nor does (DCS) give us any reason to think that God has not merely permitted but also commanded or endorsed the suffering of the Crusades, the holodomor, or clergy sexual abuse. The primary reason that theists should be concerned about the skepticism of divine command skepticism is that it undermines our ability to assess the possibility of divine reasons in situations where we already have some independent, prima facie reason for believing that God has issued an apparently horrendous command. In such circumstances, if something like (DCS) really does follow from the skepticism of skeptical theism, then the skeptical theist cannot use her limited knowledge of possible goods, possible evils, and the entailment relations that hold between them to rule out the possibility that the ostensible divine command is in fact veridical.

To offer a concrete contemporary example, I present Mary. To an outsider, Mary's family looks like the quintessential conservative religious family. They attend a local Southern Baptist church where Mary's parents are well-respected. They homeschool their six well-behaved and apparently happy children. But behind closed doors Mary's mom "says that she is in a war against [her children] and that God is on her side in that war...that she will keep fighting till she dies, [her children] die, or [they] are finally broken of [their] will...that in the Old Testament rebellious children were stoned to death and that's what [her children] deserve" (Mary 2013). Mary's account that follows these words includes the most horrific forms of religiously-motivated child abuse that I have ever encountered. To compare Mary and her siblings to Ivan's child would not be a significant stretch (Dostoyevskiy 2003, 316). What distinguishes Mary from Ivan's little girl is that Mary's parents engage in this behavior believing (or at least claiming to believe) that they are 'training up their children in the way of the Lord.' The quote from Mary's mother above is a clear reference to Deuteronomy 21:18-21, which commands the Israelites to bring a rebellious son before the elders of the land and for him to be stoned to death for his rebellion. ${ }^{10}$ Mary's parents reason that if God commands torture leading to death in the case of rebellion, then certainly any brutal punishment short of torture to death is permissible and even praiseworthy. I charge that the skepticism of divine command skepticism renders the following kind of judgement illicit for Mary and Mary's siblings: “God couldn't have a morally sufficient reason for commanding that we be treated this way, therefore either God did not issue the command in Deuteronomy or my parents are misunderstanding its content or application," or, to put it as young children might actually express it, "If God really loves us, God couldn't want mom and dad to treat us this way!" (DCS) doesn't give Mary a reason to believe that God commands her suffering. She already has that. ${ }^{11}$ (DCS) deprives her of an important kind of moral inference that would

\footnotetext{
${ }^{10}$ Indeed, I know from personal conversation of at least 10 additional victims of religiously motivated child abuse in evangelical communities where the very same passage was used to explain and justify God's supposed endorsement of the abuse. It is important to note that this is not how the Jewish community has interpreted or applied this text. It appears, rather to be the interpretation the arises of a the very particular conservative evangelical hermeneutical methodology.

11 This is the important difference between Mary and Rea's "Lucy." Lucy doesn't have any reason to think that God commanded or endorsed the sexual abuse she experienced at the hands of her neighbor (2013, 495-497). Mary does have such a reason both from the Bible itself and from her parents' testimony about God.
} 
provide a rebutting defeater for the view that divine love includes endorsements of brutally beating, starvation, and exposure of one's children to the elements.

As I noted in the introduction, religious scriptures are often just the handiest club for bludgeoning one's neighbor. But in some cases of violence in the name of God, there appear to be "true believers" who engaged in the atrocities against the witness of their conscience just because one must obey God's commands whatever they may be, trusting that God has reasons beyond one's ken. On a more public and popular level, readers may be familiar with Christians who express dismay for "having" to kick their gay child out of the house, excommunicate pregnant teenagers, or deny the priesthood to woman. However, such Christians do just that despite their discomfort because of a genuine belief that they are obeying God. Indeed, anyone who has ever tried to argue someone out of such practices is likely familiar with the refrain, "God's ways are higher than our ways." Although few lay Christians are in a position to appeal directly to the skepticism of skeptical theism, the things they do say suggest that they rely on something like this skeptical inference to explain their refusal to reject putative divine commands that they themselves find repugnant. There is a deep and disturbing resonance between the arguments of the skeptical theist and the arguments offered by those who cruelly "discipline" their children in the name of God, who demand that wives submit to abusive husbands, and who insist that it was wrong for enslaved Americans to flee their oppressors.

\section{Skeptical Theism and Scriptural Hermeneutics}

In this section, I turn to two broad categories of theological and hermeneutical methodology to consider how they fair with respect to (DCS). Within theological traditions of liberation-such as Latin American liberation theology, Black liberation theology, Feminist theology, Womanist theology, and Mujerista theology (Gutierrez 1973; Cone 1986; Johnson 2002; Brock and Parker 2001; Williams 2013; Copeland, 2018; Pinda-Madrid 2011) — theologians tend to start from the assumption that some social group, unified by commonalities of social experience and sense of group identity (Young 1990, 40-42), has a particular standing within the spiritual economy. ${ }^{12}$ The familiar slogan of Latin American liberation theologians is a "preferential option for the poor." The idea is not that the poor are naturally spiritually superior to the rich (although it may be easier for a camel to pass through the eye of a needle than for a rich person to enter the kingdom of heaven), but that God is on their side because they are marginalized and oppressed by the powers of this world.

12 Offering a metaphysical analysis of social groups is beyond the scope of this paper, but for the sake of a cursory analysis, Iris Marion Young's distinction between aggregates, associations, and groups may be instructive. On Young's analyses, aggregates are any classification of persons according to some attribute, associations are formally organized institutions such as churches, clubs, or political parties, while a social group is a collective of persons differentiated from at least one other group by their similar experiences, cultural practices, way of life or their sense of group identity. Young claims that individuals are metaphysically prior to aggregates and collectives, but groups are metaphysically prior to individuals, and they are real, not as substances, but as a kind of social relation $(1990,40$ 42). 
Womanist, feminist, and Mujerista theologians and biblical scholars assume that God is on the side of women who are oppressed as women in general, as women of color, as poor women, as disabled women, etc. Elisabeth Schussler Fiorenza claims:

The 'advocacy stance for the oppressed' must be sustained at the point of feminist critical evaluation of biblical texts and traditions and their authority claims; the personally and politically reflected experience of oppression and liberation must become the criterion of appropriateness for biblical interpretation. (Fiorenza 1985, 32)

Similarly Elizabeth Johnson claims that, "Christian feminist liberation theology is reflection on religious mystery from a stance which makes an a priori option for the human flourishing of women" (Johnson 2015, 17).

In a paper of this length, it would be impossible to explore the rich, diverse, and complex relationships that exist within liberation traditions between the hermeneutical principles endorsed by diverse biblical scholars, on one hand, and the theological views of diverse theologians on the other. And so, much complexity will be glossed over. However, three widely accepted methodological assumptions within these traditions of biblical interpretation and theological scholarship are worth considering: 1) that the text of the Christian scriptures, including the Hebrew Bible and the Christian New Testament, are inspired by God and offer something of value to the Christian community, 2) that God has morally sufficient reasons for promoting the flourishing of the oppressed, and 3) that God lacks morally sufficient reason to command their oppression or to endorse attitudes, practices, and social structures that would promote their oppression. The first assumption is important, not only because it places the work of these scholars within the general Christian tradition, but also because it demonstrates the connection that is assumed between how we interpret the Bible on one hand, and how we live in Christian community on the other. Liberation theologians, like most of the Christian tradition, assume that we can learn something about what God is like and what God wants for God's people from the Bible. In the introduction to Womanist Midrash: A Reintroduction to the Women of the Torah and the Throne, womanist biblical scholar, Wilda Gafney, places her use of her "sanctified imagination," which centers those to or for whom "often the text does not speak, or even intend to speak...let alone hear," within a tradition that "respects the Scriptures as the word of God and takes them seriously and authoritatively" (3). She simultaneously acknowledges a belief in the inspiration of Scripture and the importance of not misrepresenting it, while also proclaiming that "our wrestling [with the text] should not be taken to mean that we affirm texts that do not affirm us" (8). As I read her, Gafney is asserting that whatever God intends to communicate to God's people in and through the text is authoritative, but it need not always be identified with the oppressive perspectives expressed by the human authors of the text or even their understanding of God's character and commands. Womanist theologian Delores Williams takes a related stance, expressing approval when anthropologist Lawrence Levine describes the relationship of African Americans under slavocracy with the Biblical 
text as one that "did not accommodate themselves to the Bible [but] rather...accommodated the Bible to the urgent necessities of their lives" (Williams 1993, 3). But even as Williams rejects the assumption that womanist theology must "accommodate itself to the text," her very practice of Biblical appropriation for the sake of developing a womanist theology - which takes the form of careful analysis of and reflection on the story of Hagar-underscores a commitment to the idea that the text has something to offer God's people.

But, of course, the text does not just present the Divine will in an unmediated way to our understanding. The texts must be interpreted. The later two principles are, therefore, brought to bare in applying the first. When someone working within this milieu encounters a biblical text that makes it seem as though God endorses oppression, they will prefer an interpretation according to which oppression is not an expression of the Divine will. When reflecting on the tradition of sexual slavery in the Torah and on the ways in which this tradition was used to justify the transatlantic slave trade and the sexual assault of Black women in the US, Gafney writes,

These passages illuminate the gulf between the god of the text and God beyond the texts. The authority of these texts is the authority that is given to these texts by the communities that canonized them and and those that receive them...Some of us outright reject the god of slavery in or out of the Scriptures. (2017,

Gafney is so thoroughly convinced that a good and loving God could not have a morally sufficient reason for endorsing the sex slavery of vulnerable women that she interprets the many passages that seem like explicit or implicit endorsements of such slavery as a manifestation of the skewed perspective of the human biblical authors who could not imagine a social order without access to the bodies of low-status women. She rejects any interpretation on which this could be a manifestation of Divine Revelation.

For many theologians in the liberation tradition, the failure to interpret the Christian scriptures from the perspective of the most marginalized in society-what Williams calls the "womanist hermeneutic of identification-ascertainment" (Williams 1993, 132) - is partially responsible for the development of theological theories that ultimately encourage oppression. Privileged theologians and Biblical scholars do not always bother to consider what bad practical implications their theories and interpretations might have for those less privileged than themselves. One example that has received significant attention is Anselmian atonement theory (Williams 1993, Pineda-Madrid 2011, Brock and Parker 2001). According to Pineda-Madrid, Anselm develops a theory that centers the perspective of a ruling-class man. God's honor must be restored the way the honor of a feudal lord must be restored when he has been slighted. Jesus restores God's honor by his willingness to undergo suffering as an innocent. To follow Jesus, from within such a framework, means being willing to suffer and die like Jesus did, and being willing to suffer and die as an innocent makes one especially pleasing to God (Pineda-Madrid 2011, 88-89; Brock and Parker 2001, 1836; Williams 1993, 142-148). For the women who have been encouraged to submit willing to violence, oppression, and forced surrogacy in order to be more like Jesus, 
the Cross becomes just one more example of why God needs the powerless to passively endure their own oppression. But reading the Biblical text and evaluating the Christian theological tradition from the perspective of the powerless and the oppressed, under the assumption that God does not have sufficient reason to endorse attitudes and principles that would promote oppression, would show these theories to be false.

Let's call the methodological principle illustrated by the above theologians and biblical scholars (LT)_Liberation Theology:

(LT) There is no morally sufficient reason that could justify God in issuing a command, $c$, or endorsement, $e$, that promotes injustices against an oppressed group. ${ }^{13}$

But (LT) is a direct contradiction of (DCS),

(DCS) No human being is justified (or warranted, or reasonable) in thinking the following about any ostensible divine command $c$ or endorsement $e$ that is (i) logically consistent, and (ii) does not require the performance of an action that is an absolute moral wrong: there is (or is probably) no reason that could justify God in issuing command $c$ or endorsement $e$.

If (DCS) follows from the skepticism of skeptical theism just as (ST) does, then skeptical theism is incompatible with methodological principles adopted by the liberation theologians described above. That is, we cannot consistently respond to the problem of evil by invoking our ignorance about the realm of value without also sacrificing our ability to embrace liberation theologies and a fundamental option for the oppressed.

One might object that (DCS) does not strictly contradict (LT) if promoting injustices against an oppressed group is absolutely morally wrong. The problem with this solution to the problem is that injustice, unlike lying or killing, is a broad, morallyvalanced action-type, and the broader moral landscape is critical in evaluating whether any particular act counts as an injustice or not. While some act might be an injustice if a human engaged in it with their limited moral knowledge, if a divine being knew some good that would be achieved or evil averted by it, then God would not be commanding an injustice if God commanded it. Indeed, this very sort of reasoning is often offered to explain apparent atrocities in the Bible. The Divine command to slaughter the Amalekites looks like a command to commit genocide-a good candidate for an injustice and, indeed, an absolute moral wrong. But Eleonore Stump has argued that there are possible worlds very similar to ours (and perhaps identical to ours) where there are God-justifying reasons for such a command, and so, given God's reasons, in that possible world the Israelites would be rationally and morally justified

\footnotetext{
${ }^{13}$ If one is uncomfortable with the identity politics entailed by "socially oppressed group" I invite them to see LT as a specific application of a more general principle LTG: No morally sufficient reason could justify God in issuing a command, c, or endorsement, e. that promotes injustice." Although not an identical principle, Michael Rea argues in favor of a related claim, "If God exists, believing the truth about God would not promote injustice," in his response to Kathryn Pogin (Rea 2020, 310).
} 
in accepting the command as divine and in obeying it (Stump 2011). It is unclear whether a skeptical theist can reject the possibility that God has such reasons. So, it is unclear whether the skeptical theist can appeal to provision (ii) of (DCS) to escape the apparent conflict.

The implications of this conflict are, of course, far-reaching. But for the purposes of the current paper I am interested in the impact it has on our practices of scriptural hermeneutics in cases like Mary's and those Gafney addresses above. We saw above that if (DCS) is true, Mary would not be rationally justified in inferring that God could have no morally sufficient reason for wanting her parents to treat her in the ways that they did. Gafney's rejection of the laws that allow for slavery and prevent enslaved women from going free (as enslaved men do, according to the text) stands in stark contrast to the hermeneutical approaches of men like Rousas Rushdooney, the so-called "father of American reconstructionism," and his follower David Barton. Barton argues that, given the divine commands found in the Hebrew Bible, "we cannot say that slavery, in a broad and general sense, is sin (2016)." He goes on to acknowledge that while many practices of American chattel slavery were sinful, if the rules governing slavery found in the Scriptures are followed (which includes rules like Exodus 21:7, which provides that a man can sell his daughter into slavery and that she may not gain her freedom as male slaves do, and rules, like Leviticus 19:20, which treat the rape of an enslaved woman as a crime against her owner and not something bearing the same penalty as the rape of a free woman, although Barton does not address them), ${ }^{14}$ there is nothing inherently morally wrong with the practice in general. Rushdooney himself describes the Biblical law regarding slavery as "humane and also unsentimental" $(1973,251)$. Although the differences between their hermeneutical methodology and Gafney's are myriad, the one that stands out most starkly here is that Gafney uses her pre-theoretical commitment to the flourishing of Black women as a guide for where to find the true will of God in the text. Barton and Rushdooney start from no such place. Rather, they draw conclusions about what reasons God must have on the basis of what God has (from within their broader hermeneutical framework) commanded. The existence of such putative commands leads them to conclude that "some people are not able to maintain a position of independence" (Rushdooney 1973, 485-486). Of course, one does not have to be a liberation theologian to reject the notion that slavery is permissible, but, as I shall argue below, even those hermeneutical moves are often implicitly motivated by one's moral judgements.

As someone who finds the liberation theological traditions compelling, a conflict between skeptical theism and (LT) constitutes a prima facie reason against skeptical theism for me. But I have no illusions that all of my fellow analytic theologians and philosophers of religion will find this conflict troubling. "All the better!" an analytic theologian might think, "skeptical theism clarifies precisely the moral mistake that liberation traditions tend to make. They presume to know more about God and

\footnotetext{
${ }^{14}$ Tellingly, Barton ignores the unique provisions described for enslaved women and describes "Biblical slavery" as (1) always voluntary, and (2) temporary unless voluntarily made permanent, although it could be permanent for non-Israelites, and so, according to them, and so the permanent enslaved of Africans could only be justified if they did not accept Christianity.
} 
God's reasons than any human could possibly know." I want to suggest that the conflict runs deeper and applies more broadly. While the liberation theological traditions are explicit about bringing their pre-theoretic moral commitments to the theological table, more traditional and 'conservative' hermeneutical practices do as well-but in a way that remains largely invisible to the practitioner. William Larkin, for example, argues that, "[u]nless one becomes consciously aware of [one's]...preunderstanding through which the text passes and acts to correct it, one probably will misinterpret and misapply the text's content" $(1988,99)$. That is, Larkin claims that unless the interpreter of scripture recognizes that she has pre-theoretic moral commitments and lays them aside to view the text unhindered, she is likely to misunderstand it. However, when it comes to morally difficult passages and those that seem in apparent conflict with other parts of the canon, Larkin himself encourages the principle of allowing Scripture to interpret scripture. At first glance, this appears to be a rejection of allowing one's moral commitment to influence one's interpretation. But when one begins to look at the actual practice, which passages are given precedence over which others ultimately depends (usually implicitly rather than explicitly) on the moral intuitions of the exegete.

Take for example two different more "traditional" approaches to interpreting and applying Ephesians 5: "Wives, submit to your own husbands, as to the Lord...so let the wives be to their own husbands in everything." That last phrase, "in everything" is a strong universal statement-one that has the potential (and has actually been used) to subject women to all manner of abuse (Brock and Parker 2001). Biblical Scholars and theologians like Gafney, Williams, Brock, Parker, Pineda-Madrid, and Johnson can easily reject any interpretation that would command submission to abuse on the basis of (LT). Scholars like Larkin will have to set aside any "preunderstanding" of what a loving God has reasons to command that might cause them to balk at the idea of requiring a wife to submit to a violent husband, in favor of the "clear meaning of the text" and letting Scripture interpret scripture.

Which passages are relevant in the search for consistency? In one sense, all of them. But for the sake of brevity, let's consider at least two relevant passages. On one hand, the exegete inclined to think that the scope of "in everything" must be narrower than a truly universal statement-someone like Timothy Keller, who argues that a "wife should not obey or aid a husband in doing things that God forbids, such as selling drugs or physically abusing her" (Keller 2011, 242) - must contend with passages like 1 Peter 2:18-21, which explicitly instructs Christians to submit to earthly authorities even in the face of violence and abuse. On the other hand, interpreters inclined to take the scope of "in everything" as absolute must acknowledge a tradition of refusing to obey unjust and immoral commands from worldly authority: "we must obey God, rather than man" (Acts 5:29). However, someone like John Piper who does endorse near absolute submission is well aware of this tradition, and thus makes a distinction between enduring abuse and being asked to participate in sin. He argues that "if he's not requiring her to sin, but simply hurting her, then I think she endures verbal abuse for a season, she endures perhaps being smacked one night" (Piper 2009, emphasis mine). In light of these apparently conflicting themes in the scriptural and interpretive tradition in Christianity, it appears that both pastors are implicitly relying 
on their "preunderstandings" to guide them with respect to which theme to prioritize in making their hermeneutical judgements, even as they reject the permissibility of doing so in the explicit way that the liberation theologians do.

However, one might argue that rather than relying on sinful and purely human preunderstandings, the theologian should actually rely on the moral intuitions that have been formed in a character developed in the grip of the Christian scriptures and traditions, guided by the Holy Spirit. ${ }^{15}$ For example, one might think that the doctrine of the Imago Dei provides a helpful guiding moral principle that would justify prioritizing one interpretation over the other. Being created in the Imago Dei gives all Christian theologians a reason to believe in the fundamental dignity and great moral value of every human person regardless of their social identities. However, upon reflection, it appears that to be justified in believing that a particular interpretation of an ostensible morally problematic divine command - to be justified in believing that commanding wives to submit to abuse-is inconsistent with the Imago Dei (or neighbor love or human dignity or any other moral principle taught by the Christian tradition), one has to be justified in believing that God does not have an over-riding morally sufficient reason that would justify commanding something that appears, prima facie, incompatible with the Imago Dei (or neighbor love or human dignity). We would need to be warranted in believing that God does not have an over-riding moral reason, as the doctor does in my vaccination example, in order to make the inference that one interpretation is more compatible with the Imago Dei than the other. And that is precisely what (DCS) says that we cannot be justified in believing.

It appears that without a principle like (LT) someone like Larkin or Keller cannot be justified in claiming that Ephesians does not require that women or children or slaves submit to brutality. They have no good reason, in the absence of a judgement about the relative moral goodness of the interpretations, to prefer their own interpretations to Piper's. But it seems like they should! Similarly, Mary cannot get a defeater for the reasons she already has for thinking that God endorses the abuse she experienced. But it seems like she should! If my argument is successful, then skeptical theism is not only inconsistent with liberation traditions, but with many of the more familiar hermeneutical moves in "traditional" theology and Biblical interpretation. Indeed, it undermines the very grounds that "moderate" Christians usually have for rejecting the more "extreme" Biblical interpretations of those sometimes labeled "fundamentalist" or extremists. And that, to my mind, is reason enough to reject it.

At this point, it is important to note a significant dissimilarity between the cases to which skeptical theism is intended to apply and the cases to which divine command skepticism applies. In the case of divine permission of evil, that the evil has occurred is not in question. It is actual, and the skepticism of skeptical theism explains why its existence does not render the theist irrational in continuing to believe in God. Given our epistemic limitations, we are rarely, if ever, in precisely this position with

\footnotetext{
15 Indeed, that seems to be the general direction of Rea's argument in the paper referenced above above. I will set aside the fact that it seems that either "preunderstanding" could equally easily develop for a person living in the grip of the Christian scriptures and its traditions depending on which strains one chooses to emphasize, if the witness of Christian history is any guide.
} 
respect to God's commands. Indeed, that we are not is precisely why (DCS) is a concern. In the case of any ostensible horrific divine command or endorsement, a theist has two options: they can conclude that God must have reasons beyond their ken for commanding or endorsing the apparent horror, or they can conclude that they have mis-identified or misinterpreted the command in question. The epistemic humility characterized by skeptical theism renders the second horn an ever-present possibility. I acknowledge that a theist could have any number of reasons to doubt that they have properly identified or interpreted an ostensible divine command. Surely if the apostle Peter thought he was obeying God when he initially rejected the command to kill and eat unclean animals, then the common Christian should not expect to be beyond mistakes. The skeptical theist who rejects the interpretation of the Christian scriptures that Mary's parents endorse could still say to them, "You can't be sure that your interpretation, and not mine, is the right one." The argument I have presented here only counts against making the judgement that, because it appears to the theist that there is no God-justifying reason to command something, that there is not such a reason. That is, the theist cannot use a disjunctive syllogism to rule out the possibility that God has good reasons for issuing the command in order to decide in favor a different interpretation. Of course, in individual cases there may indeed be all manner of historical and textual reasons to reject some particular morally problematic interpretation, but we cannot assume $a$ priori that there are in every case. Furthermore, many of us, myself included, believe that one need not have any sophisticated education in Biblical hermeneutics to know that Mary's parents are wrong, both in their behavior and in their interpretation of the Bible. We think that everyone should know, in virtue of having the very basic moral knowledge that humans have, that this interpretation is wrong. So, while it may not be impossible, in principle, for the skeptical theist to avoid the "bad" interpretations in many cases, they will not be able to use the reasons that I think they often do use. But perhaps more importantly, the skeptical theist cannot use a reason that many of us believe they should be able to use. Indeed, as I mentioned above, the refusal to make these judgements is precisely what more progressive theists find so outrageous about those who, on the grounds of embracing "the clear meaning of the text," like Piper or Rushdooney, encourage obedience to merely ostensible but clearly horrific divine commands. We want to be able to say to Mary's parents, "You should have known that God does not want you to beat or otherwise abuse your children, and you didn't need to go to seminary to know it!" I claim that the skeptical theist has lost the grounds on which to stand in issuing such a critique.

\section{Conclusion}

Skeptical theism is an attractive response to the problem of evil, especially for those who, like me, find the reasons for allowing apparently gratuitous suffering that most other theodicies and defenses offer morally disturbing. In this paper I have argued 
that if appropriate epistemic humility should lead us to embrace (ST) then it should also lead the skeptical theist to embrace (DCS). But (DCS) undermines a wide range of interpretive practices that should be viable interpretive resources for the theist and which theists actually use in making sense of their religious traditions. Therefore, we should deny that appropriate epistemic humility leads to (ST).

As a theist myself, I do not intend this paper as a defense of atheism. Rather, I intend it as an argument, and, indeed a plea, that we take seriously and put deep, careful, and extended thought into tracing the potential results of our moral theorizing about God. If I am right, skeptical theists have some serious work to do to formulate their skepticism in ways that do not lead to these troubling results. But even if skeptical theists reject my conclusions, I hope that my argument has demonstrated why someone might, in the grip their skeptical arguments, think that it leads to the conclusions I have suggested. Indeed, as I have noted above, the kinds of responses that religious folks often give to moral objections to their religious practices suggests that lay Christians often do think that the epistemic humility of skeptical theism promotes such conclusions. Given the potential dangers, I believe that it is incumbent on the skeptical theist to take pains to demonstrate why these conclusions do not follow from the principles that they endorse. One of Eva Kittay's principles of ethical philosophizing is that we "pay attention to the consequences that may be implied by [our] philosophical account" (Kittay 136, 2008). If Kittay can demand this of non-religious philosophers, how much more should philosophers of religion, most of whom worship a God who commands care for "the least of these," follow her principle? Robert Mesle states,

My question...is not really about God, but about the human beings who write theodicies. God does not write them, we do. And I believe we human theologians must be held accountable for the ethical implications of our pictures of God. It is no good to excuse ourselves by pleading that God is exempt. We human theologians are not. If we paint God so that a person who acted in the same way would be a moral monster...then there is something wrong with our theology, something that does not make the world better for children. (2004, 252).

I say, if we paint God such that humans cannot know that someone behaving like a moral monster is not obeying God's commands, then there is something wrong with our analytic theology, something that makes the world worse for the least of these. 


\section{References}

Adams, Marilyn McCord, Horrendous Evils and the Goodness of God, (Ithaca: Cornell University Press, 1999).

Ahmed, Shahab, "Ibn Taymiyyah and the Satanic Verses" Studia Islamica 87 (1998): 67-124.

Bennett, Jonathan, "Acting and Refraining," Analysis, 28 (1967): 30-31.

Bergmann, Michael, "Skeptical Theism and The Problem of Evil" in The Oxford Handbook of Philosophical Theology, ed. Thomas P. Flint and Michael C. Rea, (Oxford: Oxford University Press, 2011).

Brison, Susan, Aftermath: Violence and the Remaking of the Self, (Princeton: Princeton University Press, 2002).

Brock, Rita Nakashima, and Rebecca Ann Parker, Proverbs of Ashes: Violence, Redemptive Suffering, and The Search of What Saves Us, (Boston: Beacon Press, 2001).

Burton, David, "The Bible, Slavery, and America's Founders," Wallbuilders, https://wallbuilders.com/bible-slavery-americas-founders/. Accessed May 3, 2021.

Cone, James H., A Black Theology of Liberation, Fortieth Anniversary Edition, (Maryknoll: Orbis Books, 2010).

Copeland, M. Shawn, Knowing Christ Crucified: The Witness of African American Religious Experience, (Maryknoll, NY: Orbis Books, 2018)

Downen, Robert, Lise Olsen and John Tedesco, "Abuse of Faith: 20 Years, 700 victims: Southern Baptist Sexual Abuse Spreads as Leaders Resist Reforms," Houston Chronicle, Sunday, February 10, 2019.

Dostoyevsky, Fyodor, The Brothers Karamazov, trans. Constance Garnett (New York: The Modern Library, 1937).

Frankl, Viktor E., Man's Search for Meaning: an introduction to logotherapy, trans. Ilse Lasch (Boston: Beacon Press 1962).

Fiorenza, Elisabeth Schussler, In Memory of Her: A Feminist Theological Reconstruction of Christian Origins, (New York: Crossroad, 1983). 
Gafney, Wilda C., Womanist Midrash: A Reintroduction to the Women of the Torah and the Throne, (Louisville: Westminster John Knox Press, 2017).

Gutierrez, Gustavo, A Theology of Liberation, trans. Sister Caridad Inda and John Eagleson (Maryknoll: Orbis Books, 1973).

Hereth, Blake, "Against Self-Defense" Social Theory and Practice 43, 3 (2017): 613-635.

Johnson, Elizabeth A., She Who Is: The Mystery of God in Feminist Theological Discourse (New York: The Crossroad Publishing Company (2002).

Katzenstein, David and Lisa Aronson Fontes, "Twice Silenced: The Underreporting of Child Sexual Abuse in Orthodox Jewish Communities," Journal of Child Sexual Abuse, 26, 6 (2017): 752-776.

Keller, Timothy, with Kathy Keller, The Meaning of Marriage: Facing the Complexities of Commitment with the Wisdom of God, (New York: Dutton, 2011).

Kittay, Eva, "The Ethics of Philosophizing: Ideal Theory and the Exclusion of People with Severe Cognitive Disabilities," in Feminist Ethics and Social and Political Philosophy: Theorizing the Non-Ideal, ed. Lisa Tessman, 121-146 (New York: Springer, 2009).

Larkin, William J., Jr., Cultural and Biblical Hermeneutics: Interpreting and Applying the Authoritative Word in a Relativistic Age (Eugene, Oregon: Wipf and Stock Publishers, 1988).

Lewis, C. S., God in the Dock: Essays on Theology, ed. Walter Hooper, (Grand Rapids: William B Eerdmans Publishing Company: 1970)

Lim, Daniel, "Doing, allowing, and the problem of evil" International Journal of Philosophy of Religion, 81 (2017):273-289.

Long, Todd R., "Minimal Skeptical Theism," in Skeptical Theism: New Essays, ed. Trent Dougherty and Justin P. McBrayer, 63-75 (Oxford: Oxford University Press 2014).

Mary. 2013. "Home is where the hurt is." Homeschooler's anonymous. https://homeschoolersanonymous.wordpress.com/2013/04/24/homeis-where-the-hurt-is-marys-story-part-nine/

Maitzen, Stephen, "The Moral Skepticism Objection to Skeptical Theism" in The Blackwell Companion to the Problem of Evil, ed. Justin P. McBrayer and Daniel Howard-Snyder, 444-457, (Wiley Blackwell, 2013). 
. "Agnosticism, Skeptical Theism, and Moral Obligation," in Skeptical Theism: New Essays, ed. Trent Dougherty and Justin P. McBrayer, 277-292 (Oxford: Oxford University Press 2014).

Melse, C. Robert, "Suffering, Meaning, and the Welfare of Children: What Do Theodicies Do?" American Journal of Theology \& Philosophy, 25 (2004): 247264.

Mizrahi, Moti, "If analytic philosophy of religion is sick, can it be cured?" Religious Studies (forthcoming).

Moosa, Ebrahim, 'Social Change', in A. Rippin (ed.) The Islamic World (New York: Routledge, 2008), 565-575.

Office of the Attorney General, Commonwealth of Pennsylvania, "Report I of the 40th Statewide Grand Jury," 2018.

Panchuk, Michelle, "The Shattered Spiritual Self: A Philosophical Exploration of Religious Trauma," Res Philosophica 95 (2018): 505-530.

. "Distorting Concepts, Obscured Experiences: Hermeneutical Injustice in Religious Trauma and Spiritual Violence," Hypatia (2020): 1-19.

Pineda-Madrid, Nancy, Suffering \& Salvation in Ciudad Juarez, (Minneapolis: Fortress Press, 2011).

Piper, John, "Does a woman submit to abuse?" Ask Pastor John, September 1, 2009, YouTube, https://www.youtube.com/watch?v=30kUPc2NLrM.

Quinn, Warren S., "Actions, Intentions, and Consequences: The Doctrine of Doing and Allowing," Philosophical Review, 98, 3 (1989): 287-312.

Rachels, James. "Killing and letting die," in Encyclopedia of Ehics, ed. L. Becker \& C. Becker, 947-950 (New York: Routledge 2001).

Rea, Michael, "Skeptical theism and the "too much skepticism" objection," in The Blackwell Companion to the Problem of Evil, ed. Justin P. McBrayer and Daniel Howard-Snyder, 482-506, (Wiley Blackwell, 2013). . The Hiddenness of God, (Oxford: Oxford University Press, 2019).

. "Reply to Pogin," in Contemporary Debates in Philosophy of Religion, 2nd ed., ed. M. Peterson and R. VanArragon, 310-312, (Oxford: Wiley Blackwell, 2020). 
Rowe, William L., "The Problem of Evil and Some Varieties of Atheism," American Philosophical Quarterly, 16, 4 (1979): 335-341.

Rushdooney, Rousas John, The Institutes of Biblical Law, (Presbyterian and Reformed Publishing Co., 1973).

Rutledge, Jonathan, "Skeptical theism, moral skepticism, and epistemic propriety," International Journal of Philosophy of Religion 81 (2017): 263-272.

Sehon, Scott, "The problem of evil: skeptical theism leads to moral paralysis," International Journal of Philosophy of Religion, 67 (2010): 67-80.

Stump, Eleonore "The Problem of Evil," Faith and Philosophy, 2, 4 (1985): 392423.

. "The Problem of Evil and the History of Peoples: Think Amalek" in Divine Evil? The Moral Character of the God of Abraham, 179-197 ed. Michael Bergmann, Michael Murray, Michael Rea. (Oxford: Oxford University Press, 2011).

Tobin, Theresa." Spiritual Violence, Gender and Sexuality: Implications for Seeking and Dwelling among Some Catholic Women and LGBT Catholics," in Seekers and Dwellers: Plurality and Wholeness in a Time of Secularity, ed. Philip J. Rossi, (Washington D.C.: The Council of Research in Values and Philosophy, 2016), 133-166

. "Religious Faith in the Unjust Meantime: The Spiritual Violence of Clergy Sexual Abuse," Feminist Philosophical Quarterly 5 (2019): 1-29.

Tollefsen, Christopher, Lying and Christian Ethics, (Cambridge University Press, 2016).

Tucker, Chris, "Why Skeptical Theism Isn't Skeptical Enough" in Skeptical Theism: New Essays, ed. Trent Dougherty and Justin P. McBrayer, 45- 62 (Oxford: Oxford University Press 2014).

Williams, Delores S., Sisters in the Wilderness: The Challenge of Womanist GodTalk, (Maryknoll: Orbis Books, 2013).

Zalcberg, Sara. "The Place of Culture and Religion in Patterns of Disclosure and Reporting Sexual Abuse of Males: A Case Study of Ultra Orthodox Male Victims." Journal of Child Sexual Abuse, 26, 5(2017): 590-607. 